\title{
Inventory Investment in the Recent Recession and Recovery
}

\author{
JOHN A. TATOM
}

HE behavior of inventory investment since the beginning of the $1973-75$ recession has been a dominant concern of economic analysts. Initially, this concern was motivated by a recognition that a relationship between inventory investment and changes in total output and employment has been one of the most pronounced regularities of the business cycle. This relationship appears to be such a dominant factor in previous postwar recessions that they have been referred to as "inventory recessions." 1 Consequently, inventory behavior is watched closely as at least a potential indicator of prospective changes in output and employment. More recently, attention has been focused upon the 1976 "pause" in economic growth. One of the principal hypotheses purporting to explain this situation relies heavily upon inventory investment behavior.

The 1973-75 recession was the longest and most severe in postwar experience. Its causes, at least initially, were unique." The behavior of inventory investment during the recession, while deceptively similar to that of prior recessions, was also unique. Inventory investment declined sharply during the recession, but it remained much higher than prior experience would indicate. This deviation from prior experience has had a very significant impact on inven-

\footnotetext{
${ }^{1}$ See for example, Michael K. Evans, Macroeconomic Activity: Theory, Forecasting and Control: An Econometric Approach (New York: Harper \& Row, Publishers, 1969), p. 201; Thomas $F$. Demburg and Duncan M. MoDongall, Macroeconomics: The Measurement, Analysis, and Control of Aggregate Economic Activity, 4th ed. (New York: MeGrawHill Book Company, 1972), p. 367; or Paul W. MoCracken, "Are the Gray Clouds Clearing?", Economic Outlook USA (Spring 1974), p. $1-3$.

2The causes of the recent recession have been examined by many analysts including Gardner Ackley, "Two-Stage Recession and Inflation, 1973-1975," Economic Outlook USA (Winter 1975), pp. 6-7; Denis S. Kamosky, "Another Recessiom, But Different," this Review (December 1974): pp. 15-18; Nomnan N. Bowsher, "Two Stages to the Current Recession," this Review (June 1975), pp. 2-8; and Arthur M. Okun, "A Postmortem of the 1974 Recession," Brookings Papers on Economic Activity (1:1975), pp. 207-21.
}

tory investment, economic activity, and the views of policy-makers in the first two years of recovery and expansion.

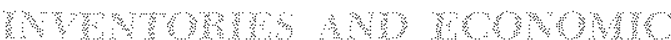 MCHIM}

Inventories consist of raw materials, work-in-progress, and finished goods. There are many reasons for holding items in inventory, such as the cost and availability of goods required in the production process, the length and flexibility of the production period, and the variability of market demand. The basic motives may be summarized as transactions, precautionary, or speculative motives.

Firms tend to hold some inventories simply to be able to meet their expected levels of sales. It is usually cheaper to acquire large lots of raw material and finished goods and hold them than to acquire raw materials as they are used, or to produce goods as they are sold. Moreover, the length of time involved in a production process requires an amount of workin-progress inventories which is directly related to the production rate. This transaction motive is based upon the requirements of daily activity and the inability to match receipts of intermediate goods and production with sales.

The precautionary motive leads firms to hold buffer stocks of inventory. This motive is based upon the risk of fluctuations in sales. Unexpected increases or decreases in sales may be met by either changing production rates or varying inventory levels. Since the costs of varying production rates can be large, firms often choose to hold a buffer stock.

The speculative motive for inventory holding rests upon the possibility of capital gains or future "shortages" of raw materials. Firms may gain by buying raw materials ahead of increases in their prices or holding 


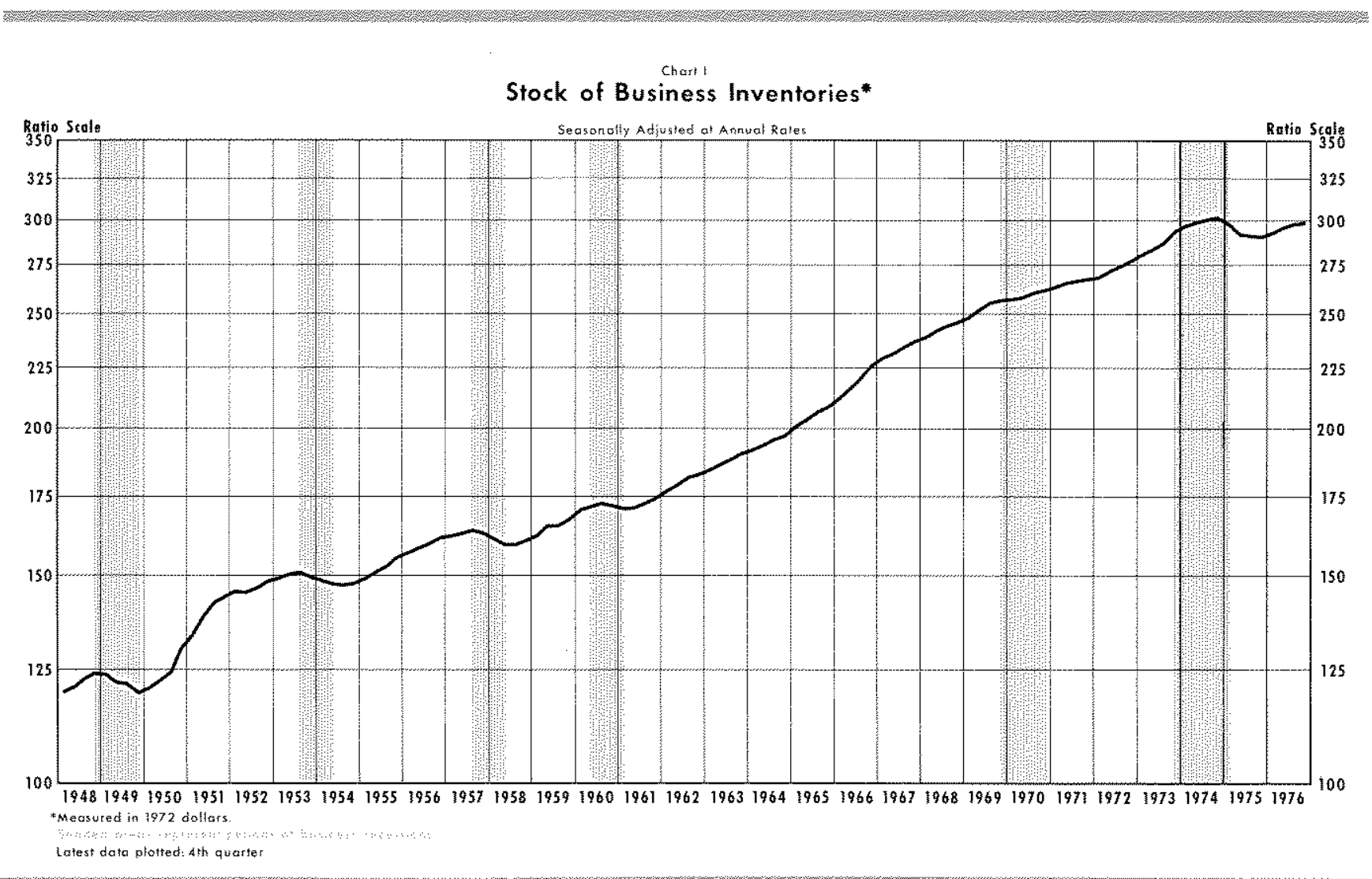

their product for future price appreciation. This type of inventory holding does not appear to be different from a precautionary motive, but it remains typical of the literature to distinguish this motive. ${ }^{3}$

It is impossible to identify the proportions of inventory held for each reason, but the motives are suggestive of the economic forces which determine the stock of inventory for the firm or the economy. The single most important factor influencing the demand for a stock of inventory is probably the expected sales rate. A larger rate of sales tends to require a larger stock of inventory. For example, the stock of business inventory in constant (1972) prices, shown in Chart I, has equaled 22 to 25 percent of real GNP since 1948. An increase in expected sales leads firms to engage in positive spending for inventories or inventory investment. If the expected growth of sales slows, firms tend to slow inventory investment. When sales are expected to decline, inventory stocks would tend to become excessive so that negative inventory investment, or disinvestment, may occur.

3See, for example, Evans, Macroeconomic Activity, p. 203. Evans also includes a backlog of demand as a reason for holding larger inventories.
Inventory investment, shown in Chart II, is a small component of production of final goods and services (GNP). For example, the largest postwar rate of inventory investment occurred in the fourth quarter of 1973 when it equaled $\$ 25.4$ billion ( 1972 dollars) at an annual rate, or about 2 percent of real gross national product. However, inventory investment is quite erratic, and changes in the rate of inventory investment can be quite large relative to changes in produc. tion rates, especially during recessions.

The sharpest swings in inventory investment and the largest positive or negative rates of investment have occurred since 1973. Quarterly rates of inventory investment over this volatile period (IV/1973 - IV/1976) are presented in Table I. After reaching its largest postwar rate in the first quarter of the recession, inventory investment declined. During the last quarter of the recession ( $1 / 1975)$, inventory investment became negative as firms depleted inventory stocks at an annual rate of $\$ 20.5$ billion. Through the first three quarters of the recovery, inventory stocks continued to decline, although at slower annual rates. Inventory investment resumed in 1976 at a fairly steady annual rate of about $\$ 10$ billion until the last quarter when it fell to about $\$ 1$ billion. 
chart ll

Actual Real Inventory Investment*

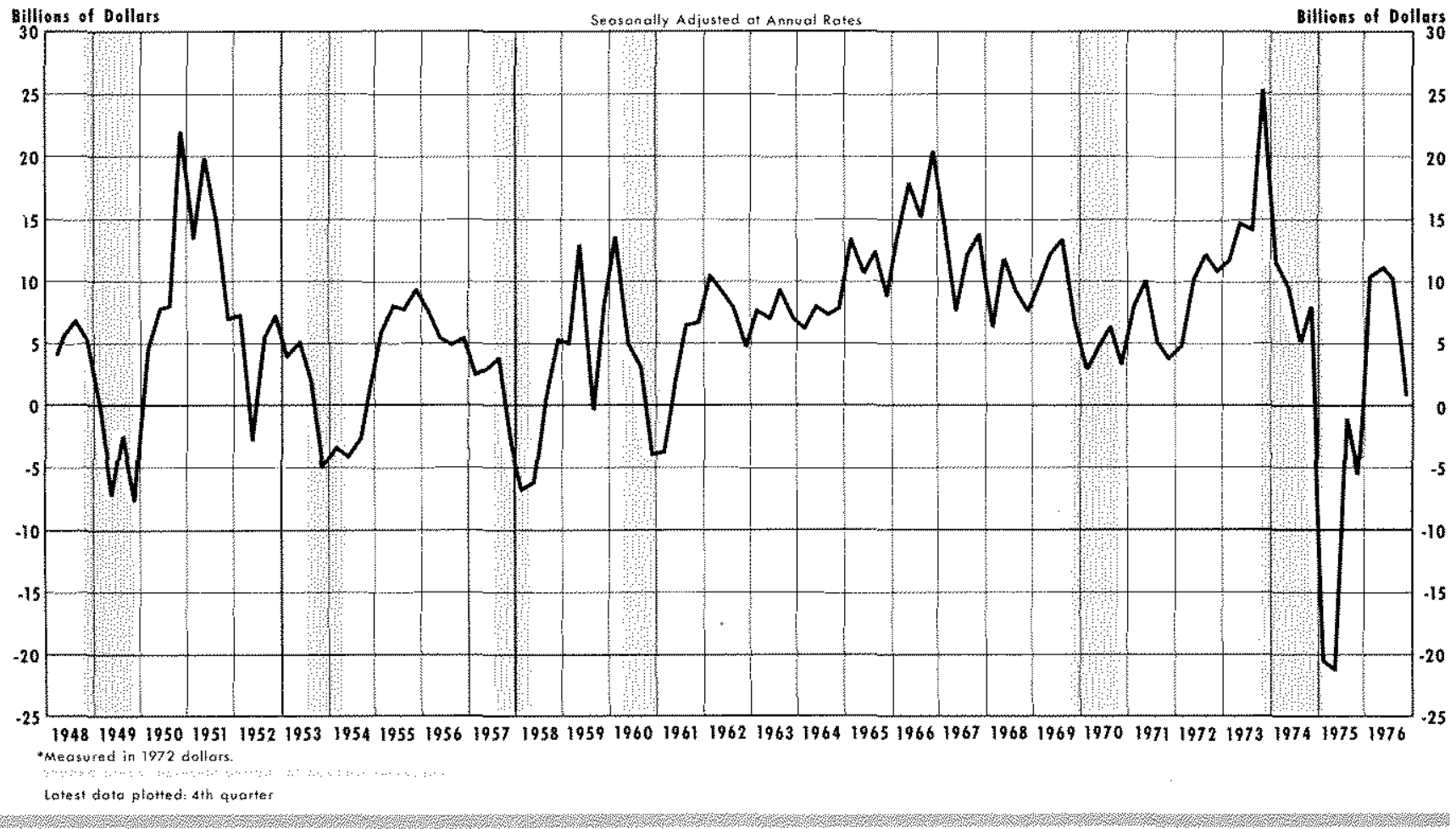

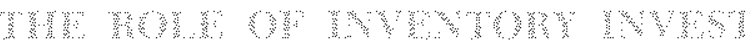

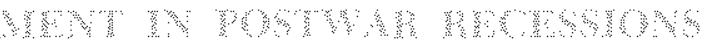

To some extent, the sharp decline in the rate of inventory investment during the recent recession was to be expected. Inventory investment had declined sharply in the five previous postwar recessions. Indeed, a major share of the decline in national output

Table

Real I Wentory Investment $(60 \mathrm{~s}$ tant 1972 bollort)
Quarters

N/1973

$1 / 1074$

$11 / 1974$

$111 / 1974$

$1 / 1974$

$1 / 1975$

$111 / 975$

$1 \mathrm{~V} / 1975$

$1 / 1976$

$11 / 1076$

$111 / 676$
$11 / 197.5$

IV/1976
Inventory Investinent

$\$ 2.5 .4$

114

9,4

5

80

$-20.5$

$-21.2$

1.0

$\checkmark 5.5$

10.4

111

10.2

0.9 during these recessions has been reflected in declines in production for inventory stocks. This is a major sense in which postwar recessions are said to be "inventory recessions."

The importance of inventory investment during recessions is reflected in the ratio of changes in inventory investment to changes in real GNP. As shown in Chart III, this ratio is usually quite small. However, there are a few quarters, primarily during recessions, when the change in inventory investment is greater than the total change in production. If output falls during such a quarter, production for inventory stock falls more, and other components - such as consumption, other types of investment, government purchases and net exports - increase. Most of the extremely high levels of the ratio of changes in inventory investment to output fluctuations occurred during recessions.

In Table II the decline in real GNP and real inventory investment, from the peak to the trough quarter, is shown for each of the six postwar recessions. In two postwar recessions the decline in the production rate was greatly exceeded by the drop in inventory investment. In three others, including the most recent 


\section{Ratio of Change in Inventory Investment to Change in Output}

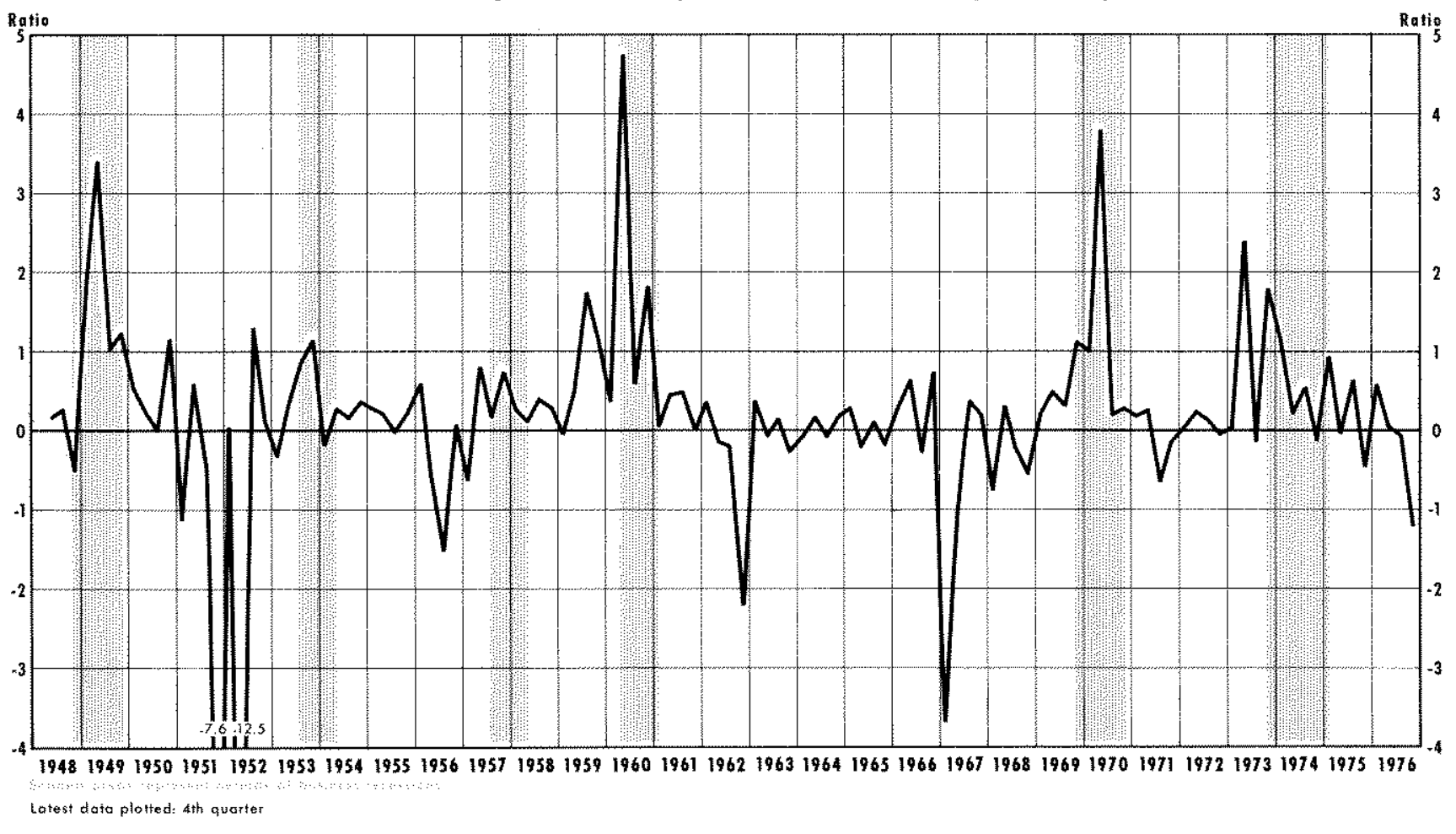

recession, the decline in the rate of inventory accumulation was about 57 percent of the decline in production. Even in the 1953-54 recession, about 36 percent of the decline in output reflected a decline in the rate of inventory investment. ${ }^{4}$

However, the notion of an inventory recession involves more than the relative size of fluctuations in inventory investment and real GNP. The more general concept of an inventory cycle, of which an inventory recession is only one stage, implies a specific sequence of changes in inventory investment before, during, and after recessions. ${ }^{5}$

\footnotetext{
4These figures may understate the role of inventory investment during recessions. For example, in the first two quarters of the $1953-54$ recession, real output declined $\$ 9.8$ billion while inventory investment declined $\$ 10.1$ billion.

5The first major theoretical attempt to explain inventory investment and the inventory cycle in terms of a relationship between desired inventory investment and changes in the level of sales is L. A. Metzler, "The Nature and Stability of Inventory Cycles," Review of Economic Statistics (August 1941), pp. 113-29. A simple explanation and numerical illustration of the inventory eycle may be found in many textbooks, including Dernburg and McDougall, Macroeconomics, pp. 367-69. A good discussion of the inventory investment models spawned by Metzler's work may be found in Evans, Macroeconomic Activity, pp. 201-20.
}

\section{Whe trowntory Crote whory}

An inventory cycle is a pattern of systematic fluctuations in economic activity associated with inventory adjustments. These adjustments are alleged to arise because the desired level of inventory stocks is related to the expected sales rate. Consequently, changes in expected sales affect inventory investment. Moreover, changes in demand for inventory investw ment also influence actual and expected sales. In this theory, such changes in investment spending are believed to affect output and employment.

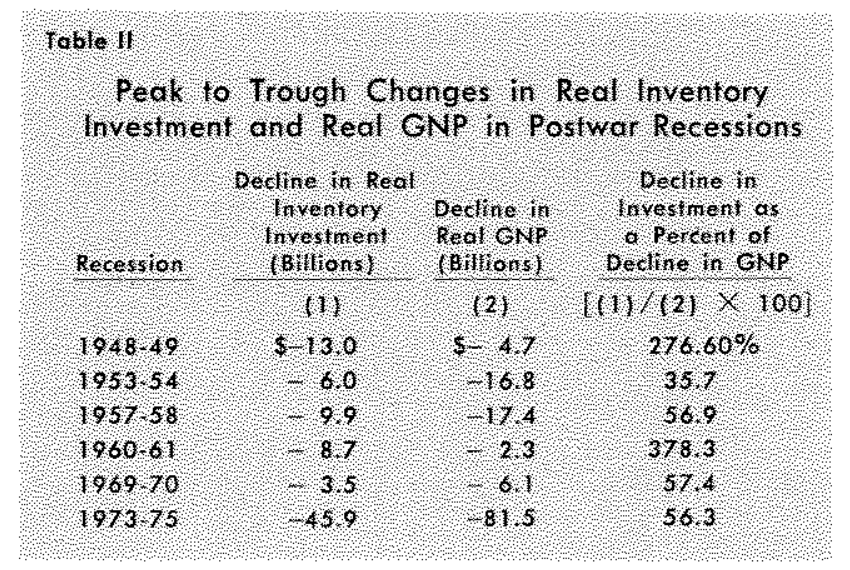


The following is a scenario of how an inventory cycle might occur. Some unexpected exogenous force increases aggregate spending and stimulates a corresponding change in production and employment. Firms, reacting to their new sales, attempt to change their inventory levels in the same direction through inventory investment. Thus, further changes in total spending, income and employment tend to occur. As inventory approaches its desired level, firms reduce their rate of spending on inventories causing aggregate demand and output growth to slow. The slowing of output growth is reinforced since it leads to a further slowing of inventory investment. The reduction in inventory investment brings sales and income growth to a halt at the cyclical peak. As inventory investment declines further, the economy enters a recession and firms may actually attempt to meet sales by selling off inventory stocks. Inventory stocks fall relative to sales so firms reach a point where inventory replacement is necessary, even to maintain the low recessionary sales rate. Inventory restocking increases demand for goods and services and provides the stimulus for a recovery and the ensuing expansion.

Two basic observations about recessions emerge from an inventory cycle theory. The first is that inventory investment declines before and during the early stages of such a recession, and often becomes negative before beginning to recover. Second, inventory investment tends to recover before the end of a recession. The pattern of inventory investment in the first five postwar recession and recovery periods shown in Chart II conforms to these relationships. ${ }^{6}$ In the first four postwar recessions, inventory investment declined before and during the recession, reached a negative rate, and recovered before the end of the recession. In the fifth recession, 1969-70, inventory investment recovered before it reached a negative rate. In this case, the rate of growth of inventory stocks slowed, but firms did not actually reduce inventory stocks as they had in the prior recessions. ${ }^{7}$

\footnotetext{
6This pattern does not demonstrate that these recessions were "inventory recessions." It does lend support to the importance of the link between changes in expected sales and inventory irvestment. This link and a monetary theory of recessions yield the same pattern of inventory investment in recessions and recoveries as that indicated by the inventory cycle theory.

TBarry Bosworth, "Analyzing Imventory Imestment," Brookings: Papers on Economic Activity (2:1970), pp. 207.27, argues that "an inventory cycle is not an adequate frame of reference" for economic developments in the 1969-71 period. Most of the argument rests upon the failure of inventory investment to becone negative during the recession although this is trot unusual in light of the extent of the decline in real output. A pattern of inventory behavior in the 1969-70 period similar to that in prior recessions may not have been evident from the preliminary data avalable in 1970 .
}

Table 11

A Simple Inventory Investment Model

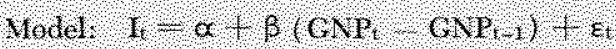

where 1 ? Gonstur Dollar linseitons hover ment in ᄂ) Ouarter?

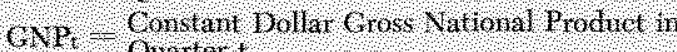
$\varepsilon_{t} \rightarrow$ andont varable

Sample,

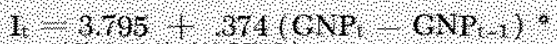

$$
\begin{aligned}
& (5.4275)(5.8513) \\
& \mathrm{S} \mathrm{C}^{2}+\frac{1}{25} \\
& \text { bw } \longleftarrow r 1
\end{aligned}
$$

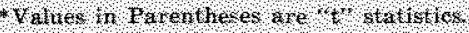

In the 1973-75 recession, inventory investment did not follow the pattern of a typical inventory cycle. Inventory investment did decline during the recent recession, but it did not decline prior to the onset of the recession. Instead, inventory investment rose sharply to its highest postwar rate during the first quarter of the recession. Moreover, inventory investment did not begin its recovery until the third quarter of 1975 , two quarters after the recession trough and did not become positive until one year after the recession trough.

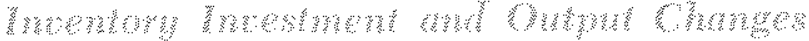

Since the notion of an inventory recession follows from a relationship between inventory investment and sales, it is useful to examine the relevance of this relationship in the postwar period. This provides a standard against which we may compare the behavior of recent inventory investment. A simple illustration of the relationship between real inventory investment and changes in real output or spending (both at annual rates) is given in Table III for the period from 1948 through the third quarter of $1973 .^{8}$ While other important factors which influence inventory investment are omitted, the relationship captures the importance of sales growth inherent in the inventory cycle theory. ${ }^{9}$

\footnotetext{
8 Changes in real GNP may not be the appropriate measure of sales, even for such a simple illustration. Several investigators have used different measures of aggregate sales. See, for example, the survey by Victor Zarnowit, Orders, Production, and Investment - a Cyclical and Structural Analysis (New York: National Bureat of Economic Research, 1973), p. 352 and pp. 362-63; or Evans, Macroeconomic Activity, p. 217.

"Current changes in real output "explain" only 25 percent of inventory investment. Also, the statistics suggest that other important factors may have been ignored. Adjustment for this potential problem, however, does not alter the conclusions drawn from Chart IV.
} 
The postwar inventory-output relationship in Table III implies the predicted inventory investment rates in Chart IV, based on output changes since 1973. The predicted pattern is very similar to the experience of previous recessions. However, the rates implied by this relationship are markedly different from the actual inventory investment behavior shown there. During the recession, actual inventory investment exceeded, by extremely large amounts, the rates implied by the postwar relationship. Beginning in the last quarter of the recession ( $1 / 1975)$ and continuing throughout the remainder of 1975 , actual inventory investment was much smaller than the rates implied by the postwar relationship.

Other factors which affect inventory investment apparently dampened the severity of the recession by keeping inventory investment high. ${ }^{10}$ "Shortages," the termination of price controls in 1973, high rates of inflation, and the fear of new price controls in 1974 probably pushed inventory investment above the levels normally desired on the basis of output growth alone. More importantly, firms apparently did not anticipate the recession, its length, or its severity, and were slow to lower production rates and inventory investment. By the end of the recession, its severity was more obvious and the excess inventory stock became apparent as well. Thus, the forces which dominated inventory investment during the recession also dominated and dampened the recovery so that throughout 1975, actual inventory investment was much lower than the simple investment-output relationship indicates.

The unusually high rates of inventory investment which apparently existed during most of the recession began in the second quarter of 1973. Accumulating the "excess" of actual investment over the amount predicted on the basis of output growth from the second quarter of 1973 yields $\$ 19$ billion of "excess" inventory stock by the end of $1974 .{ }^{11}$ The large rates at which inventory stocks were depleted in the last quarter of the recession and throughout the remainder

100kun, "A Postmortem," pp. 220-21, argues that forecasters would have predicted GNP better for the second half of 1974 if they had accounted for the inventory-ontput relationship and the inventory cycle. Using seriously erroneons predictions like those indicated in Chart IV for the second half of 1974, they would have lowered their GNP forecasts toward the actual results.

11Since the investment figures plotted in Chart IV are at annual rates, the actual addition to stocks in each quarter is one-fourth the indicated amount. Thus, excess inventory accumulation is one-fourth the amount by which each quarter's actual investment exceeds the guarter's estimated investment.

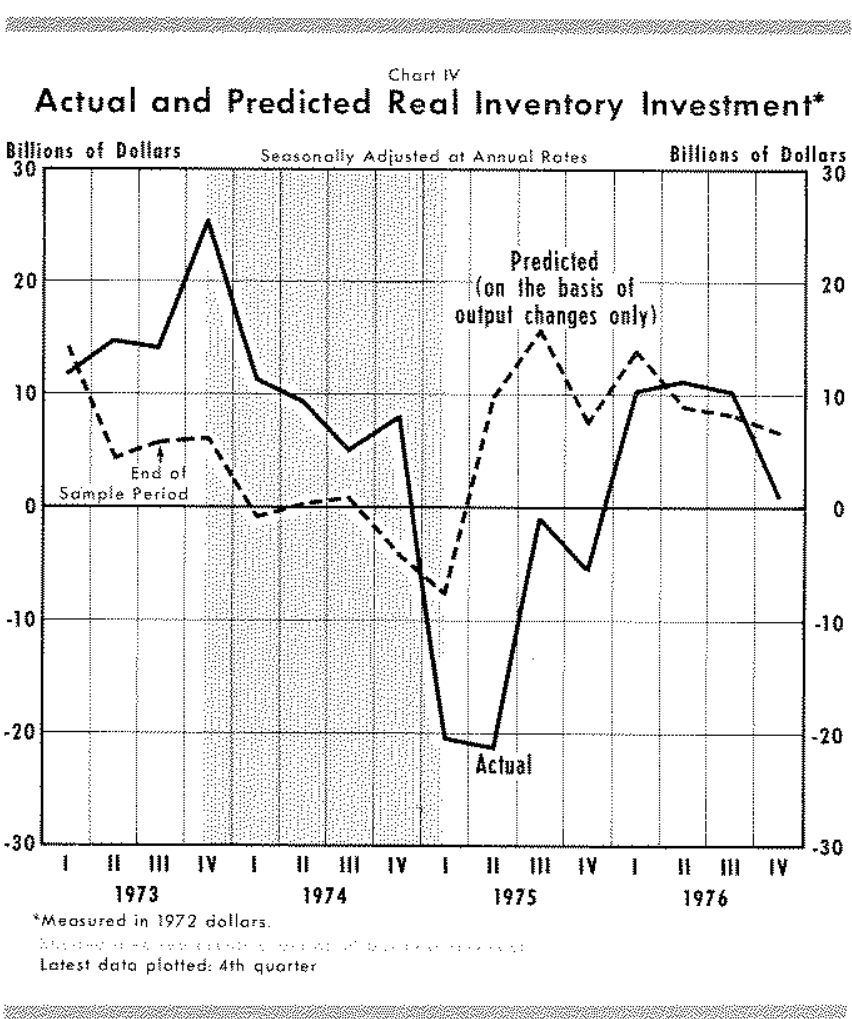

of 1975 eliminated these "excess" inventories, Adding the amount by which actual investment fell short of that implied by the postwar inventory-output relationship yields a runoff of inventory stocks of about $\$ 19$ billion. ${ }^{12}$ Thus, after the first year of recovery (1/1975 to $1 / 1976$ ) the errors have cancelled out, and the simple postwar relationship appears to hold as well as it did in the earlier period.

The behavior of inventory investment in the recent recession and recovery supports the view that firms accumulated excessive inventories (relative to output) in 1973 and that they continued to invest in excessive inventories until the end of the recession. Beginning in the last quarter of the recession and continuing through the first year of recovery, firms sold off the excess inventories, with aggregate inventory investment being negative throughout $1975 . .^{13}$ The rates of inventory investment in 1976 were to be expected

\footnotetext{
12The estimates of the excess and nun-off of inventories are intended to illustrate the process which was present in 1973-75 and not the precise extent of the problem. The actual depletion of inventory stock from the fourth quarter of 1973 to the fourth quarter of 1974 was $\$ 12$ billion (see Chart I).

13This unusual behavior of inventory investment in 1975 is a major factor in explaining the unusual changes in bank asseg portfolios during the first year of the recovery. See $R$. Altor Gilbert, "Bank Financing of the Recovery," this Review (July 1976), pp. 2-9.
} 
as they were consistent with the moderate growth of sales experienced during the year.

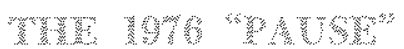

An explanation of a "pause" in a recovery in terms of the inventory cycle is that inventory is rebuilt by rapid production until firms reach a desired level of inventory stocks. ${ }^{14}$ As the inventory stock approaches its desired level, production in excess of sales in order to rebuild inventory stocks is no longer necessary so that both production growth and inventory investment slow.

Real GNP growth slowed in 1976, from a 7.3 percent rate in the first year of recovery to a 4.2 percent annual rate during the second and third quarters of 1976. This was the pause which caused increasing concern in the second half of last year. However, inventory investment did not slow during the pause. Instead, it was higher than the negative rates which prevailed throughout 1975 . Inventory investment was steadily maintained at its higher rate, hovering around $\$ 10$ to $\$ 11$ billion (constant dollars) through the first three quarters of 1976. Thus, the data are not consistent with the inventory cycle explanation of a pause $^{1 \bar{v}}$

Nevertheless, there does appear to be a connection between inventory decisions and the slowdown in growth of total output. In two quarters during the first year of the recovery (III/1975 and $\mathrm{V} / 1976$ ), there were large increases in the rate of inventory investment. In each quarter, the increase in inventory investment was matched by a sharp rise in production. In the first case ( $\mathrm{LL} / 1975$ ), inventory investment rose $\$ 20.2$ billion, but remained negative. In the second instance $(I / 1976)$, inventory investment rose $\$ 15.9$ billion to a $\$ 10.4$ billion rate.

The distorting effects of changes in inventory investment on the pattern of the recovery may be seen in Chart V. Growth of real final sales (the difference between output and inventory investment) has been relatively constant since the trough in the first quarter of 1975 . The growth rate of real GNP has been more

14The natare of the 1976 economic slowdown is discussed more fully by Neil A. Stevens and James E. Turley, "Economic Pause - Some Perspective and Interpretation," this Review (December 1976), pp. 2-7.

15It may be noted in Chart IV that the predicted inventory investment rate based upon the earlier postwar relationship in Table III follows the pattern described by the inventory cycle explanation of the pause. Following the relatively high rates of predicted inventory investment in 1955 and the first quarter of 1976 , predicted investment declines from the first through the third quarter of 1976.

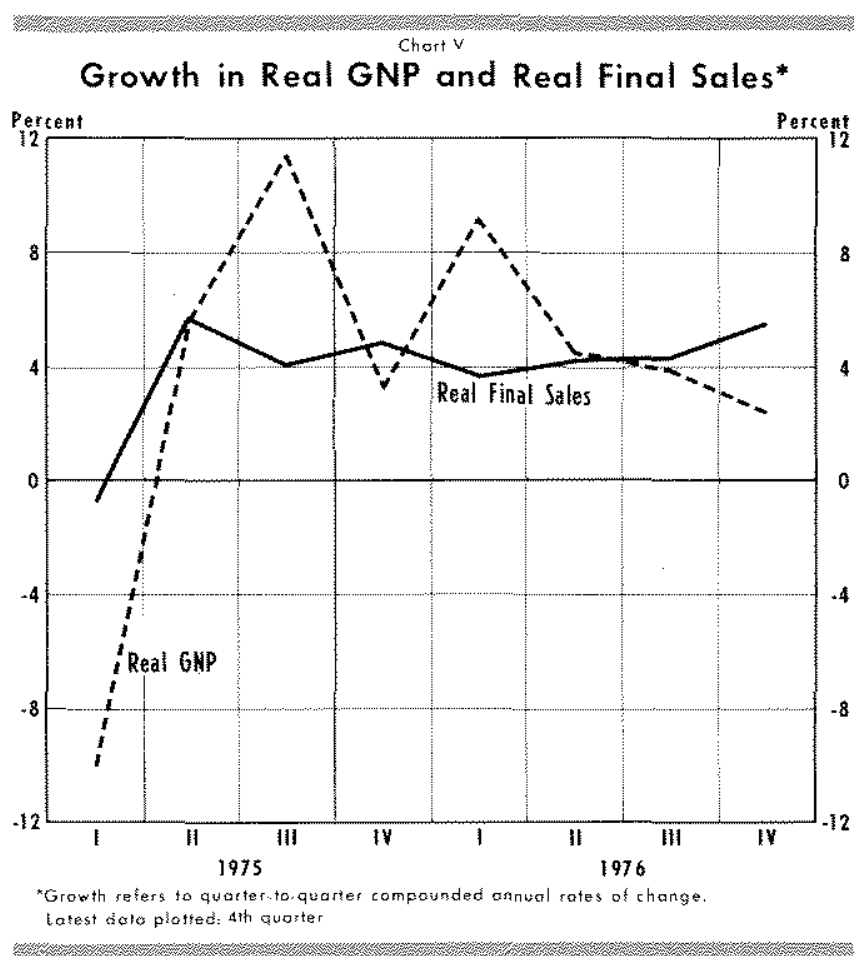

erratic. In the two quarters when inventory investment increased rapidly (III/1975 and $1 / 1976$ ), real GNP growth surged upward. These increases in inventory investment reflected the ending of the inventory stock depletion. The same rate of final sales required an increased rate of production, since firms were no longer willing to meet sales by depleting stocks.

The apparent slowdown in the rate of output growth after a year of recovery was the result of unusually high output growth in two quarters before the pause. These two surges in output growth were not due to changes in sustained forces affecting output growth. Instead, they were associated with onceand-for-all production changes required by the ending of the inventory adjustment. The rate of output growth during the period of the pause reflected the very steady moderate rate of growth of sales which has existed since the beginning of the recovery.

\section{CONOWSTON}

The behavior of inventories in the recent recession and recovery reflects the fact that businesses, like many economists, under-anticipated the severity and length of the decline in output. While the inventory investment rate declined throughout the recession, it remained positive and large, by historical standards, up to the last quarter of the recession. After the recession 
came to an end in early 1975 , businesses continued to adjust to the "excessive" levels of inventory which they had accumulated. A net inventory run-off existed in all four quarters of 1975. To the extent that inventory adjustments cause production changes, it must be said that inventory investment played a role of moderating the decline in production and employment during the recession and moderating the first three quarters of the recovery.

As the inventory adjustment came to an end, large increases in production rates were necessary to meet moderately expanding sales. The aftermath of these one-time adjustments in production rates in late 1975 and early 1976 was the apparent "pause" of 1976 . During the first quarter of 1976, positive inventory investment was restored and continued at a steady rate consistent with the moderate real output growth experienced throughout most of 1976. Production growth and inventory investment slowed markedly in the fourth quarter of 1976 and, apparently, in the first quarter of this year. If the faster growth in final sales experienced in the fourth quarter of 1976 persists, as many observers expect, inventory investment is likely to be higher in the remainder of 1977 than it was in 1976.

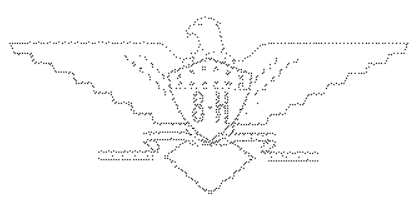

